\title{
INTESTINAL HISTOLOGY AND ENTEROCYTES HEIGHT VARIATION IN RAINBOW TROUT (Oncorhynchus mykiss) GROWN IN CAGES: EFFECTS OF ENVIRONMENTAL CONDITIONS
}

\author{
N. Savićí , B. Rašković ${ }^{2}$ Z. Marković ${ }^{2}$, V. Poleksić \\ ${ }^{1}$ University of Banja Luka, Faculty of Agriculture, Institute of Animal Husbandry, Bulevar Vojvode \\ Petra Bojovića 1A, 78000 Banja Luka, Republic of Srpska, Bosnia and Herzegovina \\ ${ }^{2}$ University of Belgrade, Faculty of Agriculture, Institute of Animal Science, Nemanjina 6, 11080 \\ Belgrade-Zemun, Serbia \\ Corresponding author: poleksic@agrif.bg.ac.rs \\ Original scientific paper
}

\begin{abstract}
Rainbow trout (Oncorhynchus mykiss, Walbaum, 1792) was grown in cages (water reservoirs "Bočac", Bosnia and Herzegovina) in two separate experiments for a period of 90 days (autumn - winter and spring summer). Trout were fed six different feed formulations and studied their influence on rainbow trout intestine histology. Normal histological structure of this part of the digestive system was found. The results showed that with water temperature and feed quantity decrease, the height of enterocytes increases; while with increase of water temperature and amount of food given to the fish, the average height of enterocytes decreased.
\end{abstract}

Key words: rainbow trout, cages, intestinal histology, enterocytes

\section{Introduction}

Significant parts of rearing technology for rainbow trout grown in cage systems are: feed choice and feeding rate adjustment according to water temperature. In addition to analyzing the effects of different types of feed on the growth parameters of rainbow trout, important indicators of the health and nutritional status of fish are the effects of various feeds on histological structure of intestine (Caballero et al., 2002, 2003; Ostaszewska et al., 2005a, b; Zakes et al., 2008; Kowalska et al., 2010).

The usefulness of monitoring the effects of different types of fish feed in order to determine positive and/or negative effects of various feed on morphological changes of fish organs, primarily organs of the gastrointestinal tract is pointed by a number of authors (Van den Ingh et al., 1991; Refstie et al., 1997; 
Fontagne et al, 1998; Peres et al., 2003; Ostaszewska et al., 2005a; Diaz et al., 2006; Fonseca-Madrigal et al., 2006; Kowalska et al., 2010; Borquez et al., 2011).

Modern feed production for salmon species is aimed at increasing the fat content in order to save expensive proteins, but also to reduce environmental pollution by nitrogen (Cho et al., 1990; Azevedo et al., 2004; Schuchardt et al., 2008). The aim of this study was to examine the impact of feed (its type and quantity) as well as the season on the histological structure of intestine of rainbow trout grown in cage system.

\section{Material and Methods}

The experiment was carried out in a cage rainbow trout farm "Tropik Ribarstvo" in a water reservoir Bočac, $50 \mathrm{~km}$ from Banja Luka, Bosnia and Herzegovina in two periods of 90 days duration. The individual body mass of rainbow trout yearlings was from 93.97 to $99.43 \mathrm{~g}$. The first cycle was carried out in autumn-winter (AW) (19 October 2005 - 24 January 2006), and another in spring-summer (SS) (02 April 2006 - 01 July 2006). Water quality parameters, regularly monitored using Oxy 330i/SET 2B20-001 (WTW, Germany), were within the first class quality during the experiment. Daily feed ratio at the experiment start was determined according to water temperature and total fish mass in cages, while feeding regime was corrected every 15 days using the same parameters.

At the beginning and end of the first and second cycle three fish per cage were sampled for histological analysis of the intestine. Prior to dissection, after the killing by severing the spinal cord and destructing the brain with the needle, fish individual weight was measured with Acculab digital balance (4800 g load). The samples of anterior intestine were taken, tying both ends and inject fixative into the intestinal lumen to prevent sealing of the intestine. Then the intestine was cut off at the ends, behind tied parts and stored in a container with fixative. Samples for histological analysis were fixed in $4 \%$ formaldehyde, paraffin embedded, cut into sections 4 to $6 \mu \mathrm{m}$ thickness, and stained with hematoxylin and eosin using standard histological procedure (Humason, 1979). Slides were analyzed and microphotographs taken by Leica DM LS microscope. Height of enterocytes was measured from the basement membrane to the brush border area using Leica Image 1000 program. 
Table 1. Feed composition used in the experiment

\begin{tabular}{|l|c|c|c|c|c|c|}
\hline Composition Feed / Feed type & $\mathbf{1}$ & $\mathbf{2}$ & $\mathbf{3}$ & $\mathbf{4}$ & $\mathbf{5}$ & $\mathbf{6}$ \\
\hline Crude proteins, \% & 44.0 & 48.0 & 42.0 & 42.0 & 44.0 & 42.0 \\
\hline Crude fat, \% & 14.0 & 26.0 & 22.0 & 23.0 & 26.0 & 18.0 \\
\hline Crude fibre, \% & 5.0 & 1.0 & 3.3 & 1.8 & 1.3 & 1.7 \\
\hline Ash, \% & 9.0 & 8.5 & 10.0 & 8.0 & 10.0 & 8.8 \\
\hline Phosphorus, \% & 1.2 & 0.9 & 1.3 & 1.1 & 1.5 & 1.2 \\
\hline Vitamin A (IU/kg) & 6000 & 15000 & 6000 & 15000 & 6000 & 15000 \\
\hline VitaminE(mg/kg) & 200 & 200 & 200 & 200 & 200 & 200 \\
\hline Copper (mg/kg) & 3.0 & 5.0 & 3.0 & 5.0 & 3.0 & 5.0 \\
\hline Gross energy(MJ) & 20.4 & 23.8 & 21.8 & 22.3 & 23.2 & 21.0 \\
\hline Digestible energy (MJ) & 17.7 & 21.9 & 19.3 & 20.3 & 20.9 & 19.1 \\
\hline Metabolic energy (MJ) & 15.7 & 19.6 & 17.4 & 18.3 & 18.9 & 17.2 \\
\hline Nitrogen-Free Extract (NFE) \% & 21.0 & 17.0 & 15.0 & 17.2 & 13.0 & 21.5 \\
\hline
\end{tabular}

The statistical methods used to analyze the results includes: average value, standard deviation, standard error of the average and coefficient of variation of the intestinal mucosa enterocytes height. With simple model analysis of variance (Ftest) and t-test were used in order to determine statistical significance between the measured parameters. The effects of different types of feed on enterocytes height were tested. Factorial analysis of variance was used to determine the impacts of growing season and type of feed on enterocytes height (Microsoft Office Excel 2003: Statistical Analysis - ANOVA).

Table 2. Average individual weight and standard deviation of rainbow trout per treatment at the start and the end of the first and second period

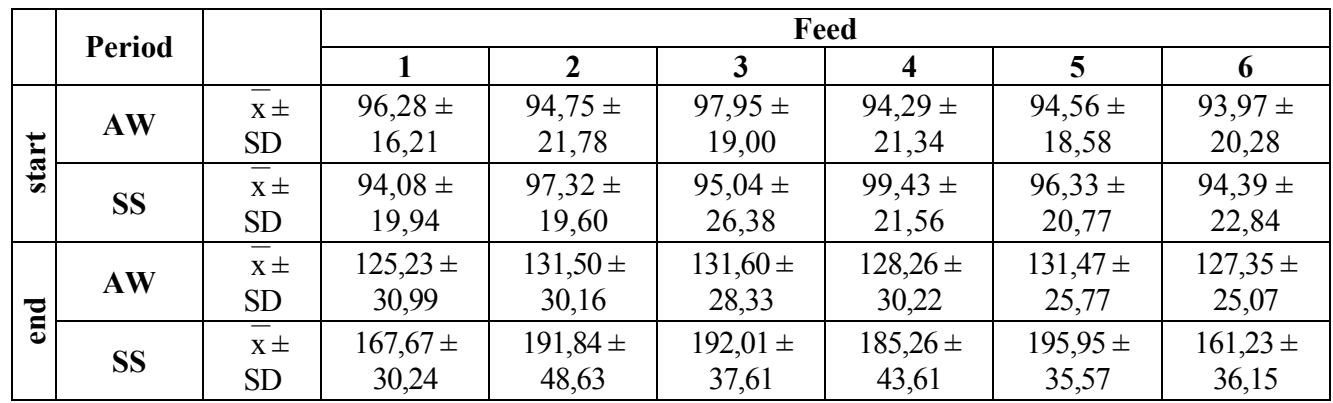




\section{Results and Discussion}

During the $\mathrm{AW}$ period water temperature ranged from $4.8^{\circ} \mathrm{C}$ (in the last 15 days) to $11.96^{\circ} \mathrm{C}$ (in the first 15 days of the experiment) (Fig. 1) while in the SS period variations were from 8.61 (in the first 15 days) to $19.37^{\circ} \mathrm{C}$ (in the last 15 days) (Fig. 2). In accordance with seasonal changes average water temperature values in the AW period have shown gradual decrease, and in the SS period gradual increase.

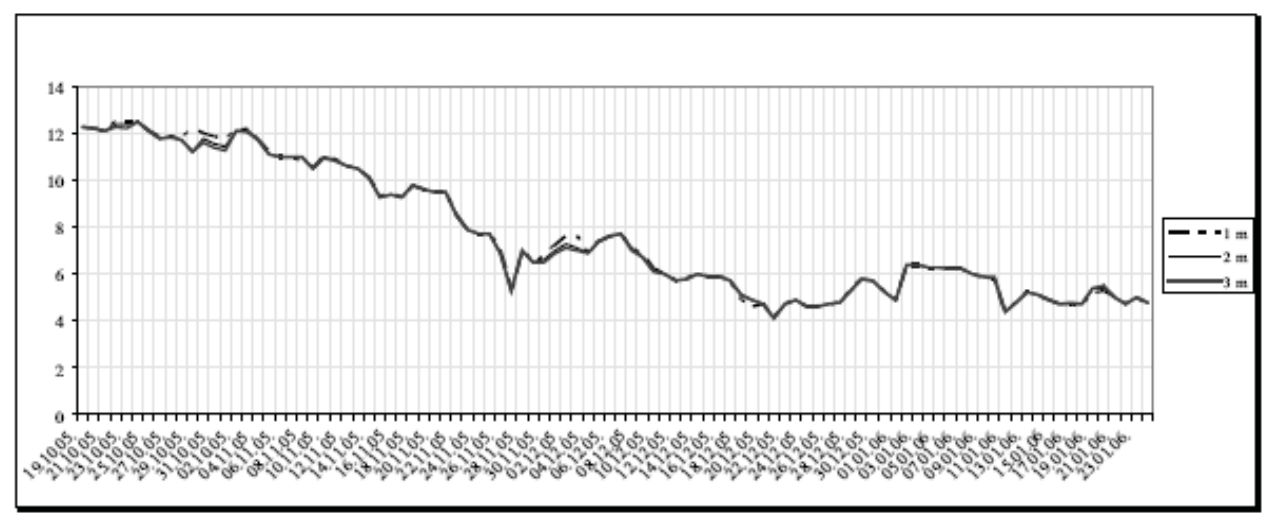

Figure 1. Water temperature variation during the AW period

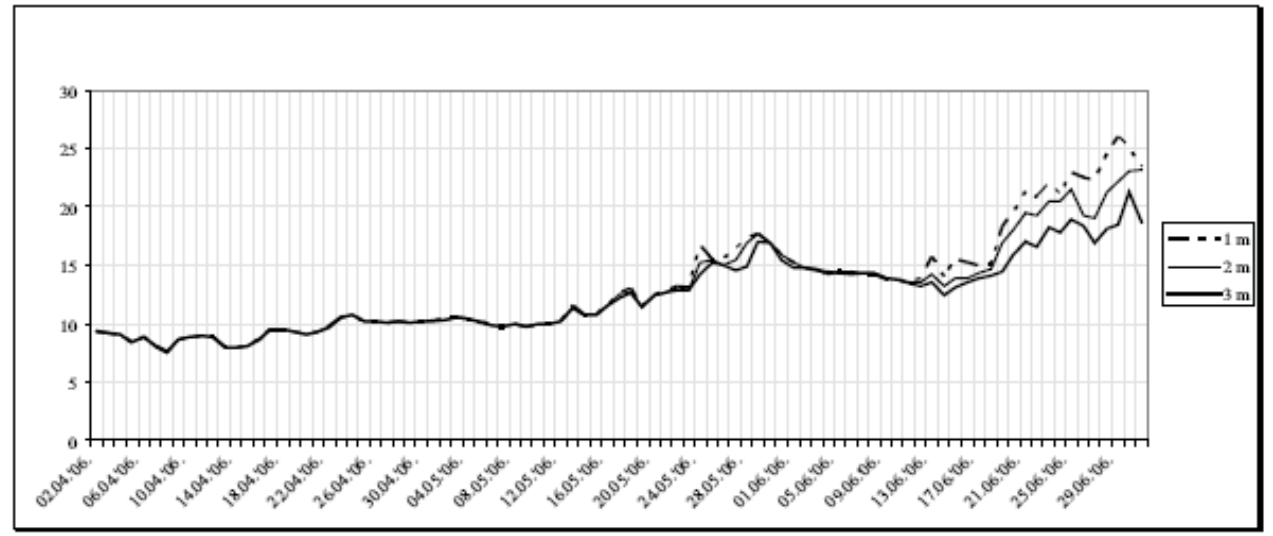

Figure 2. Water temperature variation during the SS period

The histological analysis of anterior intestine showed normal histological structure (Fig. 3): the tunica mucosa consisting of lamina epithelialis (single-layer columnar absorptive epithelial cells - enterocytes with microvilli on their apical 
part that increase absorptive capacity and goblet, mucous secreting cells) and lamina propria (connective tissue); sub-mucosal double-layered membrane (stratum compactum and stratum granulosum); muscle double-layer and serous membrane (Roberts, 1989; Takashima and Hibiya, 1995; Jutfelt, 2006). No significant alterations from the normal morphological appearance have been observed (Figure 3).

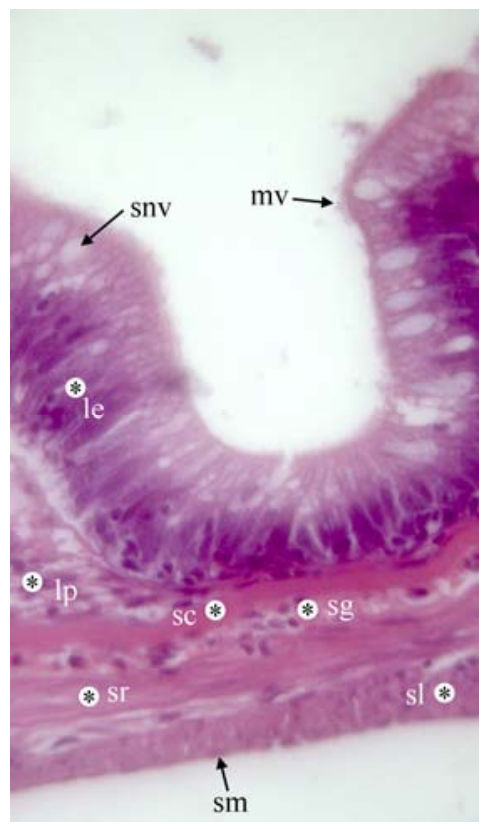

Figure 3. Histological structure of trout anterior intestine, HE, 40x:

mv - mikrovilli; snv - supranuclear vacuoles; le lamina epithelialis; $1 \mathrm{p}$ - lamina propria; $\mathrm{sc}$ - stratum compactum; sg - stratum granulosum; sr - stratum circulare; $\mathrm{sl}$ - stratum longitudinale; sm - serosa.

The results of morphometric analysis of enterocytes height from the anterior intestine are shown in Table 3 and 4. Tables present the results of $t$ - tests showing significant difference between the values of arithmetic means of enterocytes height (start-end).

Table 3. The average height of enterocytes, coefficients of variation (CV), differences between averages and $t$ - test in the $\mathrm{AW}$ cycle

\begin{tabular}{|c|c|c|c|c|c|c|c|c|}
\hline \multirow{2}{*}{ Feed } & \multirow{2}{*}{$\overline{\mathbf{x}}_{\text {start }}$} & \multirow{2}{*}{$\overline{\mathbf{x}}_{\text {end }}$} & \multirow{2}{*}{$\overline{\mathbf{x}}_{\text {start }}-\overline{\mathbf{x}}_{\text {end }}$} & \multirow{2}{*}{$\mathrm{CV}_{\text {start }}$} & \multirow{2}{*}{$C \mathbf{V}_{\text {end }}$} & \multirow{2}{*}{$\mathbf{t}_{\text {calculation }}$} & \multicolumn{2}{|c|}{$t_{\text {table }}$} \\
\hline & & & & & & & 0.05 & 0.01 \\
\hline 1 & 53.74 & 55.75 & -2.01 & 18.74 & 13.82 & 1.78 & \multirow{6}{*}{1.97} & \multirow{6}{*}{2.60} \\
\hline 2 & 41.08 & 57.77 & $-16.69^{* *}$ & 15.28 & 17.53 & $14.70^{* *}$ & & \\
\hline 3 & 49.23 & 49.40 & -0.17 & 15.17 & 21.50 & 0.14 & & \\
\hline 4 & 43.31 & 55.30 & $-11.98^{* *}$ & 18.34 & 17.59 & $10.25^{* *}$ & & \\
\hline 5 & 42.67 & 48.86 & $-6.19^{* *}$ & 18.28 & 17.03 & $5.91^{* *}$ & & \\
\hline 6 & 44.30 & 46.34 & $-2.04^{*}$ & 13.27 & 13.92 & $2.53^{*}$ & & \\
\hline
\end{tabular}

Level of significance: * $\alpha=0.05 ; * * \alpha=0.01$ 
The average height of enterocytes (first cycle) differed statistically between the beginning and end of the experiment in fish fed feed $6(\alpha=0.05)$, and in fish fed feed 2, 4 and $5(\alpha=0.01)$. The biggest difference $(16.69 \mu \mathrm{m})$ of enterocytes average height between the beginning and end of the experiment was found in fish fed feed 2, while for the fish fed feed 3 this difference was the smallest $(0.17 \mu \mathrm{m})$.

Table 4. The average height of enterocytes, coefficients of variation (CV), differences between averages and $t$ - test in the SS cycle

\begin{tabular}{|c|c|c|c|c|c|c|c|c|}
\hline \multirow{2}{*}{ Feed } & \multirow{2}{*}{$\overline{\mathbf{x}}_{\text {start }}$} & \multirow{2}{*}{$\overline{\mathbf{x}}_{\text {end }}$} & \multirow{2}{*}{$\overline{\mathbf{x}}_{\text {start }-}-\overline{\mathbf{x}}_{\text {end }}$} & \multirow{2}{*}{$\mathrm{CV}_{\text {start }}$} & \multirow{2}{*}{$C V_{\text {end }}$} & \multirow[b]{2}{*}{$\mathbf{t}_{\text {calculation }}$} & \multicolumn{2}{|c|}{$\mathbf{t}_{\text {table }}$} \\
\hline & & & & & & & 0.05 & 0.01 \\
\hline 1 & 49.387 & 42.272 & $7.11^{* * *}$ & 21.07 & 20.13 & $5.92^{* *}$ & \multirow{6}{*}{1.97} & \multirow{6}{*}{2.60} \\
\hline 2 & 50.276 & 45.149 & $5.13^{* * *}$ & 10.89 & 12.79 & $7.02^{* * *}$ & & \\
\hline 3 & 48.972 & 41.607 & $7.37^{* *}$ & 18.80 & 14.38 & $7.67^{* *}$ & & \\
\hline 4 & 51.245 & 37.868 & $13.38^{* *}$ & 13.07 & 15.14 & $16.89^{* *}$ & & \\
\hline 5 & 50.445 & 42.868 & $7.58^{* *}$ & 13.62 & 14.14 & $9.17^{* * *}$ & & \\
\hline 6 & 47.104 & 42.132 & $4.97^{* *}$ & 14.61 & 16.07 & $5.65^{* *}$ & & \\
\hline
\end{tabular}

Level of significance: $* \alpha=0.05 ; * * \alpha=0.01$

In the second cycle trend of enterocytes height decrease was marked. The biggest difference was present in treatment 4 and was lower by $13.38 \mu \mathrm{m}$ at the end from the beginning. The smallest difference was found in treatment 6 , the $4.97 \mu \mathrm{m}$ lower value of enterocytes height at the end of the experiment.

F-test $(2 \times 6)$ found significant difference $(\alpha=0.01)$ of average enterocytes height within the season (a) and type of feed (b), as well as the interaction of season and feed type (ab) as shown in Table 5.

Table 5. Factorial analysis of variance model (ANOVA), the influence of season and type of food on the enterocytes height at the end of first and second cycle and the interaction of these two factors.

\begin{tabular}{|c|c|c|c|}
\hline \multirow{2}{*}{ Source of variation } & \multirow{2}{*}{$\mathrm{F}_{\text {calculation }}$} & \multicolumn{2}{|c|}{$\mathrm{F}_{\text {table }}$} \\
\hline & & 0.05 & 0.01 \\
\hline Feeding season (a) & $770.18^{* *}$ & 3.85 & 6.65 \\
\hline Feed type (b) & $34.41^{* *}$ & \multirow{2}{*}{2.22} & \multirow{2}{*}{3.03} \\
\hline Interaction $(\mathrm{ab})$ & $31.33^{* *}$ & & \\
\hline
\end{tabular}

Statistically significant difference $(\alpha=0.01)$

Effects of feeding season (a) on the average enterocytes height indicate statistical significance $(\alpha=0.01)$ in all combinations with the feed type (b). In all combinations, there was a decline of average enterocytes height values in fish fed different types of fish feed in the SS period.

In the AW cycle lower water temperature and consequently a continuous reduction of the daily amount of food resulted in a tendency of growth of average 
enterocytes height. In the SS cycle characterized with increase of water temperature and daily food needs in relation to the mass of fish average enterocytes height, regardless of the type of feed, tends to fall.

Enterocytes size inversely proportional to water temperature and feed quantity could be explained by fish accumulating energy in the form of lipids for the coming winter period. For efficient lipid intake from feed enterocytes membrane is crucial since lipophilic molecules cross the lipid bilayer in the apical region of microvilli by diffusion, and through fatty acid transport proteins (Jutfelt, 2006). Therefore increased membrane surface area, and thus increased cell height and increased synthesis of transport proteins, could be explained as increased lipid intake from feed in preparation for overwintering.

Water temperature fall mobilize mechanisms for increased lipid accumulation from the available feed, hence an increased height of enterocytes, as found in the present study, could improve lipid absorption. In addition, synthesis of fatty acid transport proteins will also contribute to better lipid absorption (Jutfelt, 2006). In our study of hepatocytes nuclear area in the same experiment, an increase of hepatocytes nuclear area indicated increased protein synthesis in the AW period (Rašković et al., 2009). Fonseca-Madrigal et al. (2006) pointed out the interrelationship between enterocytes and hepatocytes structure in the process of HUFA synthesis in Atlantic salmon.

On the other hand, somehow unexpected, with water temperature and feed quantity increase, in this study, decrease in enterocytes height occurred. It may be speculated that when water temperature raise there is no need for excessive lipid storage since enough feed is available and water temperature increase enable effective metabolism. In the study of hepatocytes nuclear area (Rašković et al., 2009) in the SS period a statistically significant decrease was found. Certainly further research is necessary, including a laboratory study, since controlled environmental conditions could be helpful in results analysis.

Ostaszewska et al. (2005b) explain the increase in size of trout enterocytes in experiments with casein replaced with soy proteins by increased vacuolization, and accumulation of fat and/or inhibition of fatty acids re-esterification. Caballero et al. (2002) point to the accumulation of supra nuclear lipid drops in enterocytes of trout fed with oils of plant origin. Similarly, Kowalska et al. (2010) reported lipid droplets in pikeperch enterocytes fed vegetable oils. It is important to stress that all feeds tested in this study contained different amounts of lipids of plant origin.

Similarly to the present findings Fonseca-Madrigal et al. (2006) in the study of HUFA synthesis in Atlantic salmon have demonstrated that fatty acid metabolism in intestinal cells is under dual nutritional and environmental or seasonal regulation.

In a previous, shorter (60 days) experiment carried out in the spring period with same feed types, enterocytes height increased significantly only in feeds that 
had the least lipid content (14\% and $18 \%$ crude fat), the height of enterocytes of trout fed other feed types varied, variation was not statistically significant (Poleksić et al., 2006).

\title{
Conclusion
}

In the present experiment the average enterocytes height was highly dependent on the season, regardless of the type of feed: in the AW period when water temperature decreased and consequently the daily amount of food was reduced, average enterocytes height increased. In the SS period with increase of water temperature and daily food demand, average enterocytes height decreased.

In conclusion, the results obtained in this study demonstrate the influence of environmental conditions and feed quantity on enterocytes of the anterior intestine, cells responsible for nutrients, water, ions, and macromolecules absorption, pointing out the importance of organ histology in the study of different feed efficiency. Further investigation is needed to additionally explore enterocytes size decrease in the SS period and increase in the AW period.

\section{Acknowledgments}

The study was supported by Norwegian University of Life Sciences (UMB), Department of International Environment and Development Studies, NORAGRIC; Program Coordinator Dr. Mensur Vegara, professor.

\section{Histologija creva i promene u visini enterocita kod dužičaste pastrmke (Oncorhynchus mykiss) gajene u kaveznom sistemu}

\author{
N. Savić, B. Rašković, Z. Marković, V. Poleksić
}

\section{Rezime}

Dužičasta pastrmka (Oncorhynchus mykiss, Walbaum, 1792) je gajena u kaveznom sistemu (akumulacija "Bočac", Bosna i Hercegovina) u dva odvojena eksperimenta u trajanju od po 90 dana (ciklus jesen - zima i ciklus proleće - leto). Pastrmke su hranjene sa šest različitih hrana i proučavan je uticaj hrane na histologiju creva. U svim uzorcima nađena je normalna histološka slika ovog dela digestivnog sistema. Rezultati su pokazali da kada temperatura vode i količina hrane pada, visina enterocita se povećava, dok je u suprotnom slučaju, kada se temperatura vode i količina davane hrane povećava, prosečna visina enterocita opada. 


\section{References}

AZEVEDO P.A., LEESONA S., CHO C.Y., BUREAU D.P. (2004): Growth and feed utilization of large size rainbow trout (Oncorhynchus mykiss) and Atlantic salmon (Salmo salar) reared in freshwater: diet and species effects, and responses over time. Aquaculture Nutrition, 10, 401-411.

BORQUEZ A., SERRANO E., DANTAGNA P., CARRASCO J., HERNANDEZ A. (2011): Feeding high inclusion of whole grain white lupin (Lupinus albus) to rainbow trout (Oncorhynchus mykiss): effects on growth, nutrient digestibility, liver and intestine histology and muscle fatty acid composition. Aquaculture Research, 42, 1067-1078.

CABALLERO M.J., OBACH A., ROSENLUND G., MONTERO D., GISVOLD M., IZQUIERDO M.S. (2002): Impact of different dietary lipid sources on growth, lipid digestibility, tissue faty acid composition and histology of rainbow trout, Oncorhynchus mykiss. Aquaculture, 214, 253-271.

CABALLERO M.J., IZQUIERDO M.S., KJORSVIK E., MONTERO D., SOCCORO J., FERNANDEZ A.J., ROSENLUND G. (2003): Morphological aspects of intestinal cells from githead seabream (Sparus aurata) fed diets containing different lipid sources. Aquaculture 225:325-340.

CHO C.Y., KAUSHIK S.J. (1990): Nutritional energetics in fish: Energy and protein utilization in rainbow trout (Salmo gairdneri). World Review of Nutrition and Dietetics, 61, 132-172.

DIAZ A.O., ESCALANTE A.H., GARCI'A A.M., GOLDEMBERG A.L. (2006): Histology and histochemistry of the pharyngeal cavity and oesophagus of the silverside Odontesthes bonariensis (Cuvier and Valenciennes) Anatomia, Histologia, Embryologia, 35, 42-46.

FONSECA-MADRIGAL J., BELL J.G., TOCHER D.R. (2006): Nutritional and environmental regulation of the synthesis of highly unsaturated fatty acids and of fatty-acid oxidation in Atlantic salmon (Salmo salar L.) enterocytes and hepatocytes. Fish Physiology and Biochemistry, 32, 317-328.

FONTAGNE S., GEURDEN I., ESCAFFRE A.M., BERGOT P. (1998): Histological changes induced by dietary phospholipids in intestine and liver of common carp (Cyprinus carpio) larvae. Aquaculture, 161, 213-223.

HUMASON G.L. (1979): Animal tissue techniques. Freeman WH, San Francisco.

JUTFELT F. (2006): The Intestinal Epithelium of Salmonids. PhD thesis. Göteborg University, Sweden.

KOWALSKA A., ZAKĘŚS Z., JANKOWSKA B., SIWICKI A. (2010): Impact of diets with vegetable oils on the growth, histological structure of internal organs, biochemical blood parameters, and proximate composition of pikeperch Sander lucioperca (L.). Aquaculture, 30, 69-77. 
OSTASZEWSKA T., DABROWSKI K., CZUMINSKA K., OLECH W., OLEJNICZAK M. (2005a): Rearing of pike-perch larvae using formulated diets - first success with starter feeds. Aquaculture Research, 36, 1167-1176.

OSTASZEWSKA T., DABROWSKI K., PALACIOS M.E., OLEJNICZAK M., WIECZOREK M. (2005b): Growth and morphological changes in the digestive tract of rainbow trout (Oncorhynchus mykiss) and pacu (Piaractus mesopotamicus) due to casein replacement with soybean proteins. Aquaculture, 245, 273-286.

PERES H., LIM C., KLESIUS P.H. (2003): Nutritional value of heat-treated soybean meal for channel catfish (Ictalurus punctatus). Aquaculture, 225, 67-82.

POLEKSIĆ V., SAVIĆ N., RAŠKOVIĆ B., MARKOVIĆ Z. (2006): Effects of different feed types on histology of intestine and liver of the cage cultured trout. Biotechnology in animal husbandry 22, Special issue, 359-372. (in Serbian)

RAŠKOVIĆ B., SAVIĆ N., MARKOVIĆ Z., POLEKSIĆ V. (2009): Liver histology and variation of hepatocytes nuclear area of rainbow trout (Oncorhynchus mykiss, Walbaum, 1792) reared in cages. 4th International Conference „Fishery“. Faculty of Agriculture. Belgrade. Conference proceedings, 96-104.

REFSTIE S., HELLAND S.J., STOREBAKKEN T. (1997): Adaptation to soybean meal in diets for rainbow trout, Oncorhynchus mykiss. Aquaculture, 153, 263-272. ROBERTS R.J. (1989): Fish pathology. $2^{\text {nd }}$ ed. Bailliere Tindall, London.

SCHUCHARDT D., VERGARA J.M., FERNANDEZ-PALACIOS H., KALINOWSKI C.T., HERNANDEZ-CRUZ C.M., IZQUIERDO M.S., ROBAINA L. (2008): Effects of different dietary protein and lipid levels on growth, feed utilization and body composition of red porgy (Pagrus pagrus) fingerlings. Aquaculture Nutrition, 14, 1-9.

VAN DEN INGH T.S.G.A.M., KROGDAHL A., OLLI J.J., HENDRIKS H.G.C.J.M. KONINKX J.G.J.F. (1991): Effects of soybean-containing diets on the proximal and distal intestine in Atlantic salmon (Salmo salar): a morphological study. Aquaculture, 94, 297-305.

TAKASHIMA F., HIBIYA T. (1995): An atlas of fish histology. Normal and pathological features. Kodansha. Gustav Fisher Verlag.

ZAKES Z., KOWALSKA A., DEMSKA-ZAKES K., JENEY G., JENEY Z. (2008): Effect of two medicinal herbs (Astragalus radix and Lonicera japonica) on the growth performance and body composition of juvenile pikeperch Sander lucioperca (L.). Aquaculture Research, 39, 1149-1160. 